\title{
Cantuzumab Ravtansine
}

National Cancer Institute

\section{Source}

National Cancer Institute. Cantuzumab Ravtansine. NCI Thesaurus. Code C61576.

An immunotoxin of a humanized monoclonal antibody C242 (MoAb HuC242) conjug ated to a derivative of the cytotoxic agent maytansine, DM4, with potential antitumor activity. Cantuzumab ravtansine is generated from MoAb C242, which is raised against a cell surface superantigen, CA242, found in a variety of human tumor cells. Upon binding and entry, the immunoconjug ate releases the maytansinoid agent DM4, which binds to tubulin, thereby affecting microtubule assembly/disassembly dynamics. As a result, this agent prevents cell division and reduces cell growth of cancer cells that express CA242. 